\title{
Maternal Mortality Interventions: A Systematic Review
}

\author{
Gina Marie Piane, Eliva Ambugo Clinton \\ Community Health Department, National University, Costa Mesa, CA, USA \\ Email: gpiane@nu.edu \\ Received 24 July 2014; revised 20 August 2014; accepted 29 August 2014 \\ Copyright (C) 2014 by authors and Scientific Research Publishing Inc. \\ This work is licensed under the Creative Commons Attribution International License (CC BY). \\ http://creativecommons.org/licenses/by/4.0/

(c) (i) Open Access

\begin{abstract}
Background: In order to achieve the World Health Organization's Millennium Development Goal of reducing maternal mortality by three quarters by 2015 , a strong global commitment is needed to address this issue in low-income nations where the risk to women is greatest. A comprehensive international effort must include provision of obstetric and general medical care as well as community-based interventions, with an emphasis on the latter in nations where the majority of women deliver babies at home without a trained attendant. Methods: This systematic analysis evaluates interventions published in Medline and CINAHL whose outcome measure is maternal mortality. Analysis includes components of the intervention, nation and maternal death rates. Results: Nine studies documented the effectiveness of various clinical and community-based interventions, including specific drug regimens and procedures, in reducing the risk of maternal death. Six studies reported interventions that did not significantly alter maternal mortality outcomes, and the intervention in one study demonstrated increased risk of maternal death. Conclusion: The dearth of evidence highlights the need for increased focus on translational research that bridges the gap between medical advances and community-based interventions that are feasible in low-income nations. This cannot be accomplished without a stronger commitment to reducing maternal mortality by global health practitioners and researchers.
\end{abstract}

\section{Keywords}

Maternal Mortality, Systematic Review, Women's Health

\section{Introduction}

Every minute of every day, somewhere in the world, a woman dies while pregnant or while giving birth. One hundred women die every 90 minutes and 99 of these women live in countries with high levels of poverty. They 
die because they bleed to death on the way to an ill-equipped hospital or acquire an infection delivering their babies in a hut with a dirt floor. They die because their blood pressure skyrockets out of control without life saving medicines that were developed decades ago. They die because their bodies have been weakened by malnutrition, malaria, HIV, tuberculosis or diabetes. They die having abortions in secret by practitioners without training or sterile equipment. They die because their genitals were cut in childhood as part of an ancient ritual that leaves them with obstructed birth canals and scar tissue. The, more than half a million, deaths of women in pregnancy and childbirth are preventable. Medical science has had the knowledge to prevent and treat these conditions for more than one hundred years. However, preventive measures and emergency obstetric care need to be made accessible, available, affordable and acceptable to all of the women in need before progress is made.

\section{Background}

Obstetrical procedures have existed for centuries. Caesarean section may have been performed as far back as 1545 [1]. Forceps and external pelvimeters have been used since the $18^{\text {th }}$ century [2] [3]. There is evidence of the clinical use of episiotomy in the $18^{\text {th }}$ century as well [4]. The nineteenth century saw the widespread use of modern obstetric procedures and hygienic practices [5].

General medical procedures have also been available to pregnant women for centuries. The Inca had treatments for malaria before colonial times [6]. Blood pressure and its measurement were also discovered in the $18^{\text {th }}$ century [7]. Blood transfusion and the use of antibiotics drugs became indispensible therapy in the $20^{\text {th }}$ century in the industrialized nations [8] [9]. Antiretroviral drugs were patented late in the $20^{\text {th }}$ century [10]. These same life-saving techniques and treatments are still unavailable to the poor women of the world in the $21^{\text {st }}$ century.

The world is falling behind in its potential to translate medical advances into practical applications for the population. More translational research is needed to bridge the gap between medical advances and health. According to Duke University's Translational Medicine Institute, innovative behavioral, social and medical knowledge matched with community engagement and information sciences are needed to improve health on a broad scale [11]. Therefore, in order to prevent maternal mortality on a large scale, translational research is needed to bring the life-saving obstetrical and medical advances to all pregnant women in all nations through community-based interventions.

The lifetime risk of maternal death is more than 200 times greater for women in poor countries compared to women in Western Europe and North America. About 99\% of maternal deaths occur in the 53 low-income countries defined as having a GNI per capita of US $\$ 905$ or less. More than $60 \%$ of these countries are in subSaharan Africa [12]. Every two years almost one million poor mothers die from preventable pregnancy-related conditions while women in wealthy nations give birth with very little risk of death.

Maternal death is defined as "the death of a woman while pregnant or within 42 days of termination of pregnancy, irrespective of the duration and site of the pregnancy, from any cause related to or aggravated by the pregnancy or its management but not from accidental or incidental causes” [13].

The World Health Organization (WHO) is committed to achieving the Millennium Development Goal (MDG) of reducing maternal deaths by three-quarters from 1995 to 2015. Despite the global commitment to reduce the maternal mortality ratio (MMR) by $5.5 \%$ each year, the current rate of decline is less than $0.4 \%$ per annum [13]. The worldwide maternal mortality ratio was 400 per 100,000 live births in 2005. At the current rate of decline, it will take more than 188 years to meet the MDG-5 goal. A stronger commitment is needed to save these lives.

\section{Causes and Risk Factors}

Almost $75 \%$ of maternal deaths are caused by direct complications as follows:

- Hemorrhage (25\%),

- Infection (15\%),

- Unsafe abortion (13\%),

- Eclampsia (very high blood pressure leading to seizures) (12\%),

- Obstructed labor (8\%) [14].

There are several underlying causes that contribute to maternal death. In an analysis using data provided by the WHO for 168 nations, strong positive correlations were found between MMR and infant mortality rate total fertility rate poverty rate and adolescent fertility rate. Strong negative correlations were found between MMR and percentage of births attended by a skilled attendant, percentage of women using contraceptives, and adult li- 
teracy rate. Eighty-one percent of the variation in MMR can be explained by differences in IMR, percent of births attended by a skilled provider, percent of women using contraceptive, total fertility rate, adolescent fertility rate, adult literacy rate and poverty [15].

Addressing the direct causes as well as the underlying causes is essential to reduce maternal mortality. The highest risk patients need to be referred to hospitals and clinics for emergency, life saving, drugs and medical procedures to treat the direct causes. Long-term solutions will address the underlying causes as well seeking to create comprehensive systems that deliver care to all women and address community needs such as poverty, literacy and fertility rates. Interventions with strong evidence of effectiveness should be replicated and tailored to specific communities. This paper identifies the medical and community-level interventions that have been established as effective in reducing maternal mortality.

\section{Methods}

In order to find effective interventions and policies that could be used in low-income nations, a systematic review of published literature was conducted. This paper describes the first stage of analysis. A search conducted using "maternal mortality" as key words and limited to the publication years 1998-2008 resulted in 6975 titles from CINAHL and Medline databases (see Figure 1). Two hundred and seventy-six titles were animal studies and 5437 titles were not directly related to maternal mortality and were thus excluded from the compilation. After further screening the abstracts of the remaining 1262 articles, those that were not intervention studies (experimental or quasi-experimental studies) aimed at impacting the risk of maternal death were excluded. Sixteen full text articles were examined. The results are compiled below.

\section{Results}

Nine studies resulted in a decreased risk of maternal deaths (see Table 1). Studies conducted by Adewole et al. [16] and Noor et al. [17] demonstrated the effectiveness of magnesium sulphate therapy for pre-eclampsia and eclampsia. Additionally, H.E.L.P. (heparin-mediated extracorporeal low density lipoprotein precipitation) apheresis for pre-eclampsia significantly reduced disease progression, making it possible for pregnancies in the study to be continued for an average of 17.7 more days [18]. A study by Espinoza et al. [19] also found that abnormal UADV (uterine artery Doppler velocimetry) together with maternal plasma PIGF concentration of $<280 \mathrm{pg} / \mathrm{mL}$ in the $2^{\text {nd }}$ trimester served as effective risk markers for the development of pre-eclampsia and early onset and/or severe pre-eclampsia. Drape estimation of postpartum blood loss was found to be significantly more accurate than visual estimation, highlighting its utility in detecting acute postpartum hemorrhage (PPH) for prompt management [20].

A community intervention that trained TBAs (traditional birth attendants) reported a significant reduction in maternal mortality associated with trained TBA-assisted home deliveries [21]. Derman et al. [22] demonstrated the effectiveness of oral misoprostol therapy for postpartum hemorrhage. The drug was associated with a significant reduction in the rate of PPH. Another study documented significant reductions in maternal mortality associated with vitamin A supplementation [23]. Kayongo et al. [24] reported the results of CARE's FEMME (Foundation to Enhance Management of Maternal Emergencies) project to strengthen EmOC (emergency obstetric care) in five health facilities in Ayacucho, Peru. His project was successful; resulting in over $50 \%$ increased met need for EmOC, lower case fatality rates, and reduced maternal deaths.

Six studies did not significantly alter maternal mortality outcomes (see Table 2). Cleansing the birth canal with chlorhexidine did not significantly impact maternal hospital admissions and deaths due to infections [25]. Early nasal continuous positive airway pressure (CPAP) therapy, aimed at improving respiratory flow, did not prevent the occurrence of pre-eclampsia in pregnant women with pre-eclampsia risk factors [26]. Another therapy, oral $\mathrm{N}$-acetylcysteine, was not effective in preventing the progression of early onset severe pre-eclampsia and/or HELLP syndrome [27]. Giving pregnant women aspirin during the antenatal period to prevent protein uric eclampsia resulted in low, but not statistically significant, rates of protein uric eclampsia. These results did not support the use of aspirin to prevent pre-eclampsia [28].

Reproductive age women in resource-poor settings are often deficient in vitamin A, which is linked to increased risk of maternal morbidity and mortality. Results of a study where $\mathrm{HIV}^{+}$and $\mathrm{HIV}^{-}$women were given vitamin $\mathrm{A}$ in the immediate postpartum period did not significantly affect maternal morbidity and mortality among all women [29]. Additionally, training traditional birth attendants (TBAs) to provide antenatal and deli- 


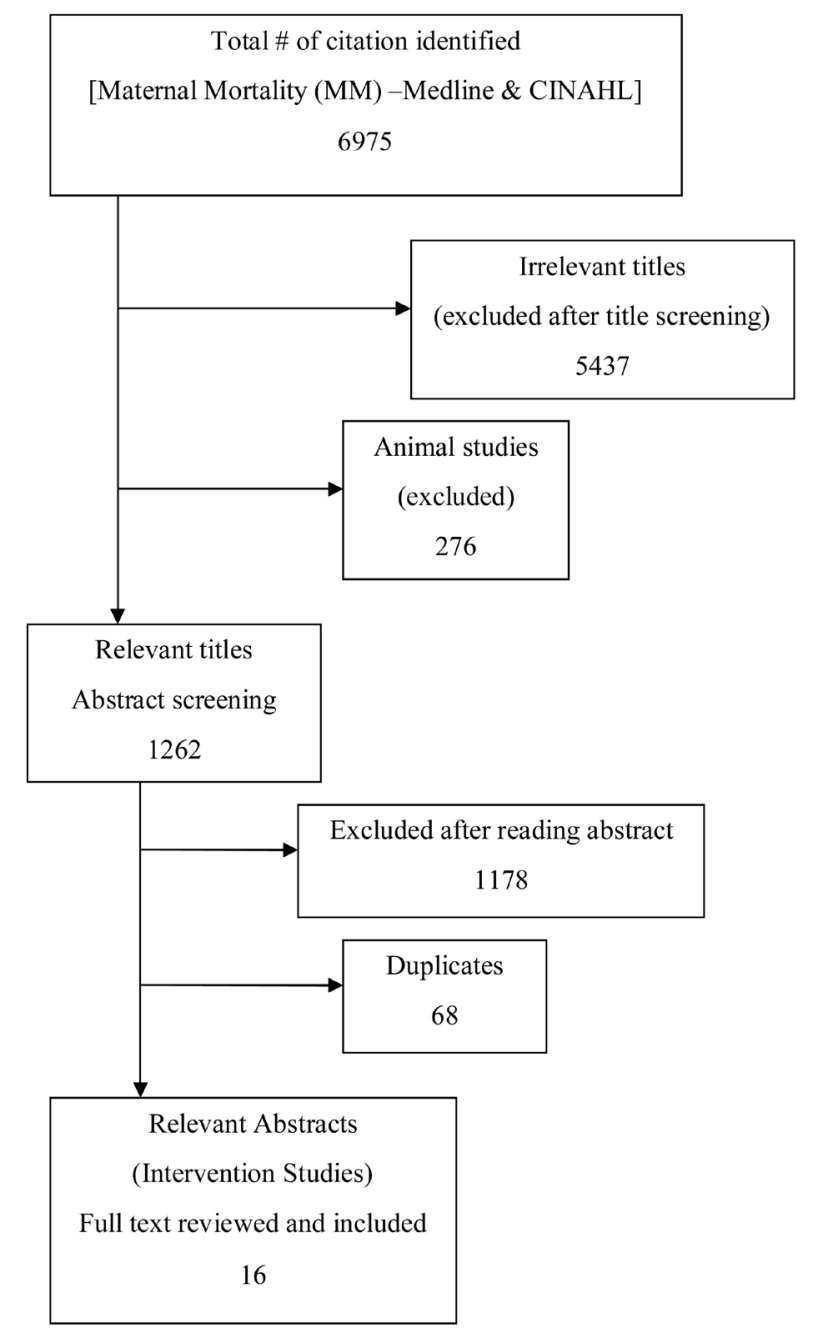

Figure 1. Included studies.

very services reduced perinatal mortality but had no significant effect on maternal mortality [30]. The results of one study (see Table 3) were associated with an increased risk in maternal death. Chigbu and Iloabachie [31] found that women who refused cesarean section when vaginal delivery was too risky had significantly poor maternal outcomes, including increased rates of maternal death.

\section{Discussion}

This Medline and CINAHL review identified 4 medical prevention strategies which were shown to produce significant reductions in maternal mortality. Magnesium sulphate and H.E.L.P. apheresis for pre-eclampsia and eclampsia [16]-[18], Oral misoprostol for postpartum hemorrhage [22], and vitamin A supplementation significantly reduced the risk of maternal death [23]. These drugs should be made available in local clinics and referral hospitals, and the medical procedures adopted in clinical settings given their effectiveness in preventing maternal deaths.

The use of abnormal UADV (uterine artery Doppler velocimetry) together with maternal plasma PIGF concentration of $<280 \mathrm{pg} / \mathrm{mL}$ in the $2^{\text {nd }}$ trimester as risk markers for the development of pre-eclampsia and early onset and/or severe pre-eclampsia should be further explored and implemented [19]. This risk assessment strategy, together with drape estimation of postpartum blood loss, will help identify the life threatening conditions of pre-eclampsia and postpartum hemorrhage and encourage their prompt management [20]. The WHO (World Health Organization) should also classify eclampsia and postpartum hemorrhage as priority conditions given 
Table 1. Procedures shown to decrease the risk of maternal death.

\begin{tabular}{|c|c|c|c|c|c|}
\hline Reference & Location & Time Period & Study Design & Study Population & Results \\
\hline $\begin{array}{l}\text { Magnesium sulphate } \\
\text { therapy for eclampsia } \\
\text { (Adewole et al., 2000) }\end{array}$ & Nigeria & 06/1997-10/1998 & $\begin{array}{l}\text { Before and } \\
\text { after study }\end{array}$ & $\begin{array}{l}\quad \mathrm{n}=21 \\
\text { Pregnant women } \\
\text { with eclampsia }\end{array}$ & $\begin{array}{l}\text { Magnesium sulphate was an effective } \\
\text { therapy for eclampsia, resulting in no } \\
\text { maternal deaths and two complications } \\
\text { : one case of oliguria and another case } \\
\text { of respiratory distress }\end{array}$ \\
\hline $\begin{array}{l}\text { Oral misoprostol therapy } \\
\text { for postpartum hemorrhage } \\
\text { (Derman et al., 2006) }\end{array}$ & India & 09/2002-12/2005 & $\begin{array}{l}\text { Randomized, } \\
\text { placebo- } \\
\text { controlled trial }\end{array}$ & $\begin{array}{l}\mathrm{n}=1620 \text { pregnant } \\
\text { women. Oral } \\
\text { misoprostol group } \\
(\mathrm{n}=812) \text { Placebo } \\
\text { group }(\mathrm{n}=808)\end{array}$ & $\begin{array}{l}\text { Oral misoprostol significantly } \\
\text { reduced the rate of acute postpartum } \\
\text { hemorrhage (from } 12 \% \text { to } 6.4 \% \text {, } \\
\qquad \mathrm{p}<0.0001 \text { ) }\end{array}$ \\
\hline $\begin{array}{l}\text { Effectiveness of UADV } \\
\text { (uterine artery Doppler } \\
\text { velocimetry) and maternal } \\
\text { plasma PIGF (placental } \\
\text { growth factor) and } \\
\text { sVEGFR-1 (soluble } \\
\text { vascular endothelial growth } \\
\text { factor receptor-1) } \\
\text { concentrations as risk } \\
\text { markers for the } \\
\text { development of severe } \\
\text { and/or early onset } \\
\text { pre-eclampsia } \\
\text { (Espinoza et al., 2007) }\end{array}$ & Chile & 01/1998-04/2004 & $\begin{array}{l}\text { Prospective } \\
\text { observational } \\
\text { cohort study }\end{array}$ & $\begin{array}{c}\mathrm{n}=3348 \\
\text { pregnant } \\
\text { women }\end{array}$ & $\begin{array}{l}\text { Abnormal UADV together with } \\
\text { maternal plasma PIGF concentration } \\
\text { of }<280 \mathrm{pg} / \mathrm{mL} \text { in the } 2^{\text {nd }} \text { trimester are } \\
\text { risk markers for the development of } \\
\text { pre-eclampsia and early onset and/or } \\
\text { severe pre-eclampsia. They were } \\
\text { associated with an "odds ratio (OR) of } \\
43.8 \text { ( } 95 \% \text { CI, } 18.48 \text { - 103.89) for the } \\
\text { development of early onset pre- } \\
\text { eclampsia, an OR of } 37.4 \text { (95\% CI, } \\
17.64 \text { - 79.07) for the development } \\
\text { of severe pre-eclampsia, an OR of } \\
\text { 8.6 (95\% CI, } 5.35 \text { - 13.74) for the } \\
\text { development of pre-eclampsia” } \\
\text { (Espinoza et al., 2007) }\end{array}$ \\
\hline $\begin{array}{l}\text { Impact of effective } \\
\text { EmOC (emergency } \\
\text { obstetric care) on } \\
\text { maternal mortality } \\
\text { (Kayongo et al., 2006) }\end{array}$ & Peru & $2000-2004$ & $\begin{array}{l}\text { Before and } \\
\text { after study }\end{array}$ & $\begin{array}{l}5 \text { health facilities } \\
\text { in Ayacucho, Peru }\end{array}$ & $\begin{array}{l}\text { There was a yearly average of } 2980 \\
\text { deliveries among the } 5 \text { participating } \\
\text { health facilities. Strengthened EmOC } \\
\text { resulted in over } 50 \% \text { increased met need } \\
\text { for EmOC, lower case fatality rates } \\
\text { (1.7\% in } 2000 \text { to } 0.1 \% \text { in } 2004) \text {, and } \\
\text { reduced maternal deaths ( } 2 \text { deaths in } \\
2004 \text { compared to } 9 \text { deaths in } 2000)\end{array}$ \\
\hline $\begin{array}{l}\text { Magnesium sulphate } \\
\text { therapy for pre-eclampsia } \\
\text { and eclampsia } \\
\text { (Noor et al., 2004) }\end{array}$ & Pakistan & $01 / 2000-12 / 2000$ & $\begin{array}{c}\text { Descriptive } \\
\text { study using } \\
\text { historical data }\end{array}$ & $\begin{array}{l}\qquad \mathrm{n}=133 \\
\text { Pregnant women with } \\
\text { pre-eclampsia }(\mathrm{n}=80) \\
\text { and eclampsia }(\mathrm{n}=53)\end{array}$ & $\begin{array}{c}\text { Magnesium sulphate reduced maternal } \\
\text { deaths. There was one death from } \\
\text { severe pre-eclampsia and } 8 \text { deaths } \\
\text { from eclampsia }\end{array}$ \\
\hline $\begin{array}{l}\text { Accuracy of drape } \\
\text { versus visual estimation } \\
\text { of postpartum blood loss } \\
\text { (Patel } \text { et al., 2006) }\end{array}$ & India & 09/2003-12/2003 & $\begin{array}{c}\text { Randomized } \\
\text { controlled study }\end{array}$ & $\begin{array}{l}\mathrm{n}=123 \text { Drape } \\
\text { estimation group }(\mathrm{n}= \\
\text { 62); Visual estimation } \\
\text { group }(\mathrm{n}=61) ; \\
\text { Pregnant women } \\
\text { having vaginal } \\
\text { delivery }\end{array}$ & $\begin{array}{l}\text { Visual estimation of blood loss was } \\
33 \% \text { less than drape estimation, a } \\
\text { significant difference }(\mathrm{p}<0.001)\end{array}$ \\
\hline $\begin{array}{l}\text { Impact of trained TBAs } \\
\text { (traditional birth attendants) } \\
\text { on maternal mortality } \\
\text { (Schaider et al., 1999) }\end{array}$ & Angola & 1994-1998 & $\begin{array}{l}\text { Quasi- } \\
\text { experimental } \\
\text { study using } \\
\text { historical } \\
\text { comparisons }\end{array}$ & $\begin{array}{c}\mathrm{n}=23,569 \text { TBAs } \\
\text { assisted home } \\
\text { deliveries. Total of } \\
1133 \text { trained TBAs }\end{array}$ & $\begin{array}{l}\text { Trained TBAs-assisted home deliveries } \\
\text { led to a reduction in maternal mortality } \\
\text { (maternal mortality associated with } \\
\text { trained TBAs }=293 \text { per } 100,000 \text { live } \\
\text { births. Maternal mortality rate from } \\
\text { historical comparisons }=1241 \text { per } \\
100,000 \text { live births) }\end{array}$ \\
\hline $\begin{array}{c}\text { Effects of vitamin A } \\
\text { supplementation on } \\
\text { maternal mortality } \\
\text { (West Jr. et al., 1999) }\end{array}$ & Nepal & 04/1994-09/1997 & $\begin{array}{l}\text { Double blind, } \\
\text { cluster } \\
\text { randomized, } \\
\text { placebo } \\
\text { controlled trial }\end{array}$ & $\begin{array}{l}\mathrm{n}=20,119 \text { women } \\
\text { became pregnant in } \\
\text { the duration of the } \\
\text { study. Placebo group } \\
\text { (n=6580 pregnant } \\
\text { women) Vitamin A } \\
\text { group ( } \mathrm{n}=7045 \\
\text { pregnant women) } \\
\text { B carotene ( } \mathrm{n}=6494 \\
\text { pregnant women) }\end{array}$ & $\begin{array}{c}\text { Maternal mortality: Placebo group = } \\
704 \text { deaths per } 100,000 \text { pregnancies } \\
\text { Vitamin A group = } 426 \text { deaths per } \\
\text { 100,000 pregnancies B carotene group = } \\
361 \text { deaths per } 100,000 \text { pregnancies } \\
\text { Vitamin A and B carotene groups }= \\
40 \%(\mathrm{p}<0.04) \text { and } 49 \%(\mathrm{p}<0.01) \\
\text { reduction in maternal mortality } \\
\text { respectively }\end{array}$ \\
\hline
\end{tabular}




\section{Continued}

H.E.L.P. (heparin-mediated extracorporeal low density lipoprotein precipitation) apheresis for pre-eclampsia

(Wang et al., 2006)
H.E.L.P. apheresis reduced "maternal circulating levels of proinflammatory and coagulatory markers of pre-eclampsia” (Wang et al., 2006). All pregnancies could be continued for an average of 17.7 more days (3 - 49 days) after initiating H.E.L.P. apheresis

Table 2. Procedures shown to have no significant difference in risk of maternal death.

\begin{tabular}{|c|c|c|c|c|c|}
\hline Reference & Location & Time Period & Study Design & Study Population & Results \\
\hline $\begin{array}{l}\text { Impact of birth } \\
\text { canal cleansing with } \\
\text { chlorhexidine on } \\
\text { mother infections } \\
\text { (Bakr et al., 2005) }\end{array}$ & Egypt & 01/2002-06/2002 & $\begin{array}{l}\text { Quasi-experimental } \\
\text { study }\end{array}$ & $\begin{array}{c}\mathrm{n}=4415 \text { women \& } \\
4431 \text { infants } \\
\text { Intervention group } \\
\text { (birth canal cleansing: } \\
\mathrm{n}=2287 \text { mothers) } \\
\text { Non-intervention } \\
\text { phase (no birth canal } \\
\text { cleansing: } \mathrm{n}=2128 \\
\text { mothers) Birthing } \\
\text { women }\end{array}$ & $\begin{array}{c}\text { Differences in } \\
\text { maternal hospital } \\
\text { admissions }(\mathrm{p}=0.09) \\
\text { and deaths }(\mathrm{p}=0.88) \\
\text { due to infections were } \\
\text { not statistically } \\
\text { significant among the } \\
\text { intervention and } \\
\text { non-intervention groups }\end{array}$ \\
\hline $\begin{array}{l}\text { CPAP (early nasal } \\
\text { continuous positive } \\
\text { airway pressure) } \\
\text { therapy for } \\
\text { pre-eclampsia } \\
\text { (Guilleminault et al., } \\
\text { 2007) }\end{array}$ & U.S.A & $\mathrm{n} / \mathrm{a}$ & $\begin{array}{c}\text { Prospective, } \\
\text { longitudinal, before and } \\
\text { after study }\end{array}$ & $\begin{array}{l}\quad \mathrm{n}=12 \\
\text { Pregnant women } \\
\text { with pre-eclampsia } \\
\text { risk factors) }\end{array}$ & $\begin{array}{l}\text { CPAP therapy does } \\
\text { not prevent } \\
\text { pre-eclampsia }\end{array}$ \\
\hline $\begin{array}{c}\text { Effects on maternal } \\
\text { mortality of antenatal } \\
\text { and delivery services } \\
\text { administered by trained } \\
\text { TBAs (traditional birth } \\
\text { attendants) } \\
\text { (Jokhio et al., 2005) }\end{array}$ & Pakistan & 03/1998-10/1998 & $\begin{array}{l}\text { Cluster-randomized } \\
\text { controlled trial }\end{array}$ & $\begin{array}{c}\mathrm{n}=19,557 \\
\text { Intervention group } \\
\text { (trained TBAs; } \mathrm{n}= \\
10,114 \text { pregnant } \\
\text { women from } 3 \\
\text { subdistricts in rural } \\
\text { Pakistan). Control } \\
\text { group (no trained } \\
\text { TBAs; } \mathrm{n}=9443 \\
\text { pregnant women } \\
\text { from } 4 \text { subdistricts } \\
\text { in rural Pakistan) }\end{array}$ & $\begin{array}{l}\text { There was no } \\
\text { statistically significant } \\
\text { reduction in maternal } \\
\text { mortality between the } \\
\text { two groups. } \\
\text { "As compared to the } \\
\text { control group, the } \\
\text { intervention group had } \\
\text { a cluster-adjusted odds } \\
\text { ratio for maternal } \\
\text { mortality of } 0.74 \text { ( } 95 \% \\
\text { confidence interval, } \\
0.45 \text { to } 1.23 \text { )" (Jokhio } \\
\text { et al., 2005) }\end{array}$ \\
\hline $\begin{array}{l}\text { Oral N-acetylcysteine } \\
\text { therapy for early } \\
\text { onset severe } \\
\text { pre-eclampsia/ } \\
\text { HELLP syndrome } \\
\text { (Roes et al., 2006) }\end{array}$ & Netherlands & 01/1999-10/2001 & $\begin{array}{c}\text { Randomized, } \\
\text { double-blind, } \\
\text { placebo-controlled trial }\end{array}$ & $\begin{array}{c}\mathrm{n}=\text { 38; Placebo group } \\
\text { (n = 19); } \\
\text { N-acetylcysteine group } \\
(\mathrm{n}=19) \text { Pregnant } \\
\text { women with severe } \\
\text { pre-eclampsia and/or } \\
\text { HELLP syndrome }\end{array}$ & $\begin{array}{l}\text { Oral N-acetylcysteine } \\
\text { administration does } \\
\text { not stop the progression } \\
\text { of early onset severe } \\
\text { pre-eclampsia and/or } \\
\text { HELLP syndrome }\end{array}$ \\
\hline $\begin{array}{c}\text { Aspirin for } \\
\text { preventing } \\
\text { protein uric } \\
\text { eclampsia } \\
\text { (Rotchell et al., 1998) }\end{array}$ & Barbados & 07/1992-07/1994 & $\begin{array}{c}\text { Randomized } \\
\text { placebo-controlled } \\
\text { trial }\end{array}$ & $\begin{array}{c}\mathrm{n}=3647 \text {; Aspirin } \\
\text { group }(\mathrm{n}=1822) \\
\text { Placebo group } \\
(\mathrm{n}=1825) \\
\text { Pregnant women } \\
\text { attending antenatal } \\
\text { care }\end{array}$ & $\begin{array}{l}\text { There were low, not } \\
\text { statistically significant, } \\
\text { rates of protein uric } \\
\text { pre-eclampsia in both } \\
\text { the aspirin and placebo } \\
\text { group. ( } 2.2 \% \text { and } 2.5 \% \\
\text { of women in the aspirin } \\
\text { and placebo groups, } \\
\text { respectively, } \\
\text { developed protein uric } \\
\text { pre-eclampsia) }\end{array}$ \\
\hline
\end{tabular}




\section{Continued}

\begin{tabular}{|c|c|c|c|c|c|}
\hline $\begin{array}{l}\text { Vitamin A to reduce } \\
\text { maternal mortality } \\
\text { (Zvandasara et al., } \\
\text { 2006) }\end{array}$ & Zimbabwe & $11 / 1997-01 / 2000$ & $\begin{array}{c}\text { Randomized } \\
\text { placebo-controlled } \\
\text { trial }\end{array}$ & $\begin{array}{l}\mathrm{n}=14,110 \\
\text { mother-infant pairs } \\
\text { Vitamin A group } \\
(\mathrm{n}=7058) \text { Placebo } \\
\text { group ( } \mathrm{n}=7052 \text { ) } \\
\text { HIV+ and HIV- } \\
\text { mothers and their } \\
\text { infants within } 96 \\
\text { hours of delivery }\end{array}$ & $\begin{array}{c}\text { Vitamin A } \\
\text { administered in the } \\
\text { postpartum period } \\
\text { did not affect } \\
\text { mortality among } \\
\text { HIV }^{+} \text {and } \\
\text { HIV }^{-} \text {women }\end{array}$ \\
\hline
\end{tabular}

Table 3. Procedures shown to increase the risk of maternal death.

\begin{tabular}{|c|c|c|c|c|c|}
\hline Reference & Location & Time Period & Study Design & Study Population & Results \\
\hline $\begin{array}{l}\text { Ceasarean section } \\
\text { refusal and maternal } \\
\text { mortality. (Chigbu } \\
\text { and Iloabachie, } \\
\text { 2007) } \\
\# 3\end{array}$ & Nigeria & 01/2004-06/2006 & $\begin{array}{l}\text { Quasi-experimental; } \\
\text { prospective controlled } \\
\text { study }\end{array}$ & $\begin{array}{l}\mathrm{n}=124 \text {, Subjects } \\
\text { (women declining } \\
\text { C-section: } \mathrm{n}=62 \text { ). } \\
\text { Controls (women } \\
\text { having C-section: } \\
\mathrm{n}=62 \text { ) Women } \\
\text { refusing caesarean } \\
\text { section when vaginal } \\
\text { delivery is too risky }\end{array}$ & $\begin{array}{c}\text { Significantly poor } \\
\text { maternal outcomes } \\
\text { among subjects }(15 \% \\
\text { maternal mortality, } \\
\text { p = } 0.008) \text { compared } \\
\text { to controls ( } 2 \% \\
\text { maternal mortality) }\end{array}$ \\
\hline
\end{tabular}

that they are the most prevalent cause of maternal death.

This Medline and CINAHL review also found that strengthening emergency obstetric care and training traditional birth attendants reduced maternal deaths [24] [21]. More research is needed to solidly establish the effectiveness of trained traditional birth attendants in improving maternal health outcomes and to establish the specific areas of training that leads to improved outcomes. In low-income nations where the majority of births are at home, effective community-based interventions are urgently needed. In order to reach the Millennium Development Goal of reducing maternal mortality by three quarters by 2015, more translational research that bridges the gap between medical advances and improved community-health is needed. There is an urgent need for more high-quality, evaluated, community intervention trials examining maternal death in low-income nations where the risk is highest. The obstetric and medical advances of the past centuries need to be made available to all of the women in the world, not just those in wealthy nations.

\section{References}

[1] Park, K. (2008) The Death of Isabella Della Volpe: Four Eyewitness Accounts of a Postmortem Caesarean Section in 1545. Bulletin of the History of Medicine, 82, 169-87. http://dx.doi.org/10.1353/bhm.2008.0030

[2] Dunn, P.M. (2004) Jean-Louis Baudelocque (1746-1810) of Paris and L'art des Accouchemens. Archives of Disease in Childhood (Fetal and Neonatal Edition), 89, 591. http://dx.doi.org/10.1136/adc.2003.044008

[3] Campbell, M. (2004) William Smellie’s Obstetrical Forceps. The Australian \& New Zealand College of Obstetricians and Gynaecologists, 44, 184-185.

[4] Cleary-Goldman, J. and Robinson, J.N. (2003) The Role of Episiotomy in Current Obstetric Practice. Seminars in Perinatology, 27, 3-12. http://dx.doi.org/10.1053/sper.2003.50000

[5] Fekete, S. (1970) Adatok Semmelweis Pesti Tanari Jelolesehez. Oryostorteneti Kozlemenyek, 55-56, $233-234$.

[6] Pinn, G. (1998) Quinine for Cramps. Australian Family Physician, 27, 922-923.

[7] Nelson, R. (2004) Blood on Demand. American Heritage of Invention \& Technology, 19, 24-31.

[8] Danic, B. and Lefrere, J.J. (2008) Transfusion and Blood Donation on the Screen. Transfusion, 48, 1027-1031.

[9] Hare, R. (1983) The Scientific Activities of Alexander Fleming, Other than the Discovery of Penicillin. Medical History, 27, 347-372. http://dx.doi.org/10.1017/S0025727300043386

[10] Gogtay, J.A. (2007) The Impact of Generic Antiviral Drugs. IDRugs, 10, 881-884.

[11] Michener, J.L., Yaggy, S., Lyn, M., Warburton, S., Champagne, M., Black, M., et al. (2008) Improving the Health of the Community: Duke's Experience with Community Engagement. Academic Medicine: Journal of the Association of American Medical Colleges, 83, 408-413. http://dx.doi.org/10.1097/ACM.0b013e3181668450 
[12] World Health Organization (2008) Why Do So Many Women Still Die in Pregnancy or Childbirth? http://www.who.int/features/qa/12/en/index.html

[13] World Health Organization (2008) Maternal Health. http://www.who.int/topics/maternal_health/en/

[14] World Health Organization (1992) International Statistical Classification of Disease and Related Health Problems. Tenth Revision, 1992 (ICD-10), Geneva.

[15] Piane, G.M. (2014) Correlates of Maternal Mortality by Nation. Open Journal of Preventive Medicine, In Press.

[16] Adewole, I.F., Oladokun, A., Okewole, A.I., Omigbodun, A.O., Afolabi, A., Ekele, B., Audu, L.R. and Obed, Y. (2000) Magnesium Sulphate for Treatment of Eclampsia: The Nigerian Experience. African Journal of Medicine and Medical Sciences, 29, 239-241.

[17] Noor, S., Halimi, M., Faiz, N.R., Gull, F. and Akbar, N. (2004) Magnesium Sulphate in the Prophylaxis and Treatment of Eclampsia. Journal of Ayub Medical College, Abbottabad, 16, 50-54.

[18] Wang, Y., Walli, A.K., Schulze, A., Blessing, F., Fraunberger, P., Thaler, C., Seidel, D. and Hasbargen, U. (2006) Heparin-Mediated Extracorporeal Low Density Lipoprotein Precipitation as a Possible Therapeutic Approach in Preeclampsia. Transfusion and Apheresis Science, 35, 103-110. http://dx.doi.org/10.1016/j.transci.2006.05.010

[19] Espinoza, J., Romero, R., Nien, J.K., Gomez, R., Kusanovic, J.P., Gonçalves, L.F., Medina, L., Edwin, S., Hassan, S., Carstens, M. and Gonzalez, R. (2007) Identification of Patients at Risk for Early Onset and/or Severe Preeclampsia with the Use of Uterine Artery Doppler Velocimetry and Placental Growth Factor. American Journal of Obstetrics and Gynecology, 196, 326.e1-326.e13. http://dx.doi.org/10.1016/j.ajog.2006.11.002

[20] Patel, A., Goudar, S.S., Geller, S.E., Kodkany, B.S., Edlavitch, S.A., Wagh, K., Patted, S.S., Naik, V.A., Moss, N. and Derman, R.J. (2006) Drape Estimation vs. Visual Assessment for Estimating Postpartum Hemorrhage. International Journal of Gynecology and Obstetrics, 93, 220-224. http://dx.doi.org/10.1016/j.ijgo.2006.02.014

[21] Schaider, J., Ngonyani, S., Tomlin, S., Rydman, R. and Roberts, R. (1999) International Maternal Mortality Reduction: Outcome of Traditional Birth Attendant Education and Intervention in Angola. Journal of Medical Systems, 23, 99-105. http://dx.doi.org/10.1023/A:1020537202451

[22] Derman, R.J., Kodkany, B.S., Goudar, S.S., Geller, S.E., Naik, V.A., Bellad, M.B., Patted, S.S., Patel, A., Edlavitch, S.A., Hartwell, T., Chakraborty, H. and Moss, N. (2006) Oral Misoprostol in Preventing Postpartum Haemorrhage in Resource-Poor Communities: A Randomised Controlled Trial. Lancet, 368, 1248-1253. http://dx.doi.org/10.1016/S0140-6736(06)69522-6

[23] West Jr., K.P., Katz, J., Khatry, S.K., LeClerq, S.C., Pradhan, E.K., Shrestha, S.R., Connor, P.B., Dali, S.M., Christian, P., Pokhrel, R.P. and Sommer, A. (1999) Double Blind, Cluster Randomised Trial of Low Dose Supplementation with Vitamin A or Beta Carotene on Mortality Related to Pregnancy in Nepal: The NNIPS-2 Study Group. British Medical Journal, 318, 570-575. http://dx.doi.org/10.1136/bmj.318.7183.570

[24] Kayongo, M., Esquiche, E., Luna, M.R., Frias, G., Vega-Centeno, L. and Bailey, P. (2006) Strengthening Emergency Obstetric Care in Ayacucho, Peru. International Journal of Gynecology and Obstetrics, 92, 299-307. http://dx.doi.org/10.1016/j.ijgo.2005.12.005

[25] Bakr, A.F. and Karkour, T. (2005) Effect of Predelivery Vaginal Antisepsis on Maternal and Neonatal Morbidity and Mortality in Egypt. Journal of Women's Health, 14, 496-501. http://dx.doi.org/10.1089/jwh.2005.14.496

[26] Guilleminault, C., Palombini, L., Poyares, D., Takaoka, S., Huynh, N.T. and El-Sayed, Y. (2007) Pre-Eclampsia and Nasal CPAP: Part 1. Early Intervention with Nasal CPAP in Pregnant Women with Risk-Factors for Preeclampsia: Preliminary Findings. Sleep Medicine, 9, 9-14. http://dx.doi.org/10.1016/j.sleep.2007.04.020

[27] Roes, E.M., Raijmakers, M.T., Boo, T.M., Zusterzeel, P.L., Merkus, H.M., Peters, W.H. and Steegers, E.A. (2006) Oral $N$-Acetylcysteine Administration Does Not Stabilise the Process of Established Severe Preeclampsia. European Journal of Obstetrics, Gynecology, and Reproductive Biology, 127, 61-67.

http://dx.doi.org/10.1016/j.ejogrb.2005.09.007

[28] Rotchell, Y.E., Cruickshank, J.K., Gay, M.P., Griffiths, J., Stewart, A., Farrell, B., Ayers, S., Hennis, A., Grant, A., Duley, L. and Collins, R. (1998) Barbados Low Dose Aspirin Study in Pregnancy (BLASP): A Randomised Trial for the Prevention of Pre-Eclampsia and Its Complications. British Journal of Obstetrics and Gynaecology, 105, $286-292$. http://dx.doi.org/10.1111/j.1471-0528.1998.tb10088.x

[29] Zvandasara, P., Hargrove, J.W., Ntozini, R., Chidawanyika, H., Mutasa, K., Iliff, P.J., Moulton, H., Mzengeza, F., Malaba, L.C., Ward, B.J., Nathoo, K.J., Zijenah, L.S., Mbizvo, M., Zunguza, C. and Humphrey, J.H. (2006) Mortality and Morbidity among Postpartum HIV-Positive and HIV-Negative Women in Zimbabwe: Risk Factors, Causes, and Impact of Single-Dose Postpartum Vitamin A Supplementation. Journal of Acquired Immune Deficiency Syndromes, 43, 107-116. http://dx.doi.org/10.1097/01.qai.0000229015.77569.c7

[30] Jokhio, A.H., Winter, H.R. and Cheng, K.K. (2005) An Intervention Involving Traditional Birth Attendants and Perinatal and Maternal Mortality in Pakistan. The New England Journal of Medicine, 352, 2091-2099. 
http://dx.doi.org/10.1056/NEJMsa042830

[31] Chigbu, C.O. and Iloabachie, G.C. (2007) The Burden of Caesarean Section Refusal in a Developing Country Setting. BJOG: An International Journal of Obstetrics \& Gynaecology, 114, 1261-1265. http://dx.doi.org/10.1111/j.1471-0528.2007.01440.x 
Scientific Research Publishing (SCIRP) is one of the largest Open Access journal publishers. It is currently publishing more than 200 open access, online, peer-reviewed journals covering a wide range of academic disciplines. SCIRP serves the worldwide academic communities and contributes to the progress and application of science with its publication.

Other selected journals from SCIRP are listed as below. Submit your manuscript to us via either submit@scirp.org or Online Submission Portal.
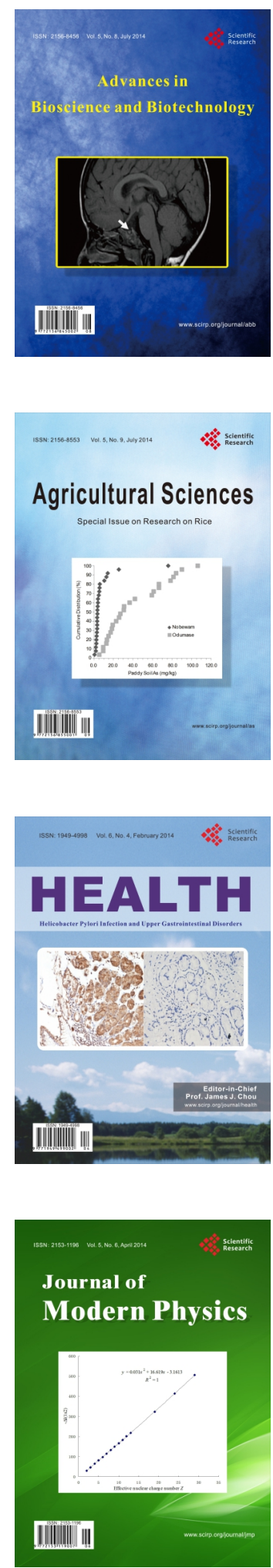
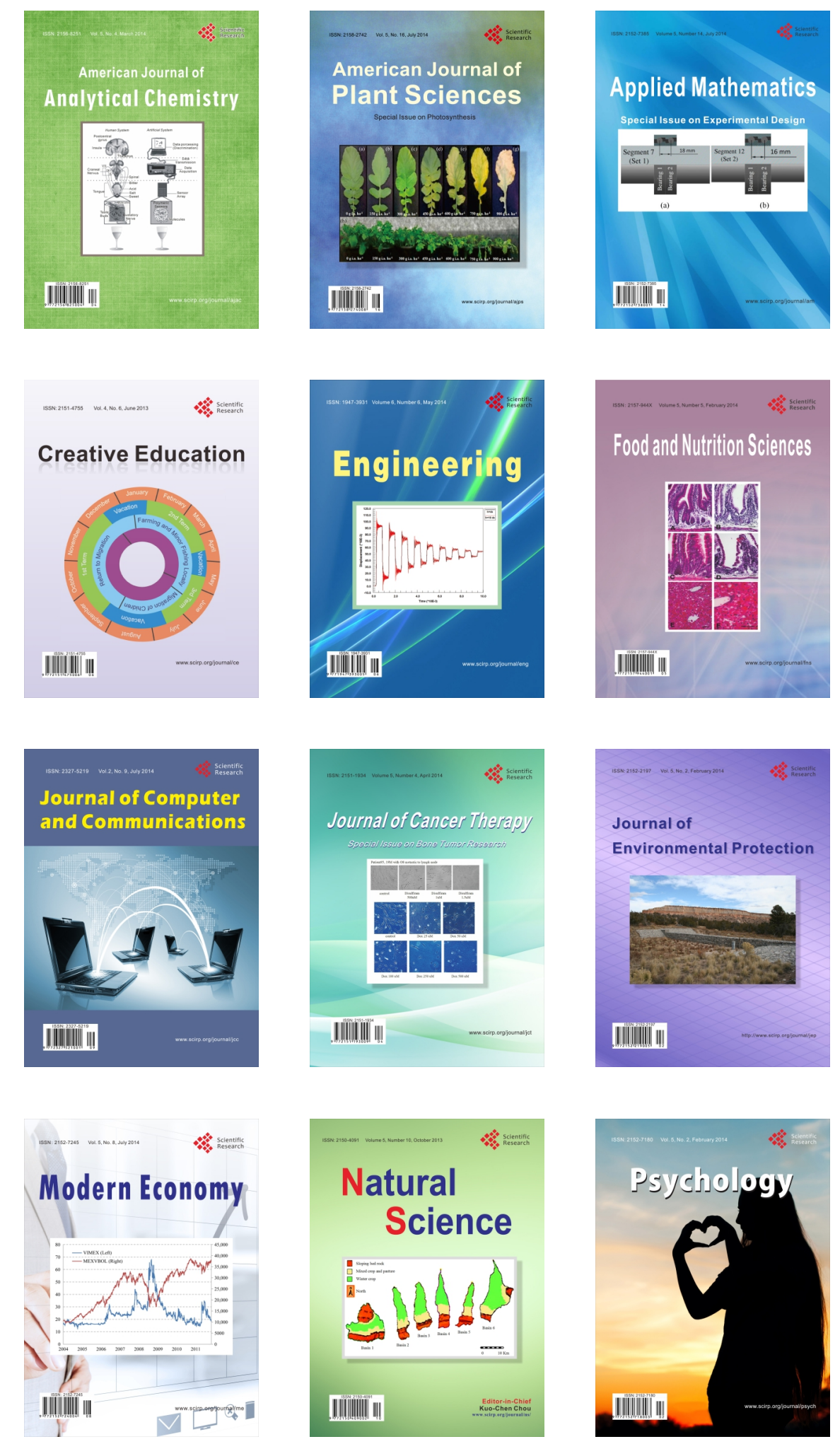